Bull. Fac. Agric., Cairo Univ., 72:13-22(2020).

\title{
PREPARATION OF GLUTEN FREE LOW PROTEIN COOKIES AND CRACKERS
}

(Received: 4. 2 .2021)

\author{
By \\ Jermine S. Fahim, Nadia M. Abd El-Moteleb and Hanan A. Hussien \\ Department of Bread and Pastry Research, Food Technology Research Institute, Agricultural \\ Research Center, Cairo, Egypt
}

\begin{abstract}
The objective of this study was to develop cookies and crackers from a mixture of gelatinized rice flour(GRF), mashed potato (MP)with cornstarch (CS) as an alternative to cornstarch (as control).This isto meet the requirements of people who need a low protein diets, such as patients with kidney diseases, or need a free gluten diets, i.e. patients with celiac disease. The results showed that protein, fat, ash, crude fiber and total carbohydrates contents of cookies and crackers produced from $100 \%$ cornstarch (control) were $(0.13,0.15 \%),(14.93,4.89 \%),(0.25,0.21 \%),(0.35,0.30 \%)$ and $(84.34$, $94.45 \%$ ), respectively. The addition of gelatinized rice flour at the level of $30 \%$ caused an increase in protein and ash $(1.90,1.83 \%)$ and $(0.54,0.45 \%)$ for cookies and crackers, respectively. Whereas, addition of $31.57 \%$ mashed potato (about $6 \%$ on dry weight basis)in cookies, had an increase in protein, fat, ash and fiber $(0.42,16.50,1.74$ and $0.68 \%$, respectively).In addition, the same trend was observed for crackers, where there was an elevation in the level of protein $(0.83 \%)$, fat $(5.92 \%)$, ash $(1.63 \%)$ and fiber $(0.65 \%)$ compared with the control (100\% cornstarch). Generally, the addition of gelatinized rice flour caused an increase in most of the minerals content. Also, the content of minerals was of a higher increase for cookies and crackersas the level of mashed potato increased,. In addition, different levels of mashed potato showed a significant effect on the diameter of cookies and crackers, where byas the level of mashed potato increased, the diameter decreased. The sensory score showed that the formula with $10 \%$ rice $+21.05 \%$ mashed potato $+70 \%$ cornstarch is the most acceptable for both cookies and crackers in overall acceptability.
\end{abstract}

Key words: Free-gluten, Low protein diets, Cookies, Crackers, Gelatinized rice flour, Mashed potato.

\section{INTRODUCTION}

Celiac disease (CD) is a syndrome characterized by damage to the mucosa of the small intestine caused by ingestion of certain wheat proteins and related proteins in rye and barley (Lerner, 2010). Wheat is the main ingredient in many foods, such as breads, breakfast cereals, cookies, crackers, pastas, and pretzels. Avoiding wheat is probably the major challenge for people with CD (Hussain et al.,2006).The effective treatment of CD includes a lifelong gluten-free diet. Therefore, providing $\mathrm{CD}$ patients with a variety of nutritious and healthy products is important. However, it is a challenge to manufacture bakery products without wheat, since gluten is responsible for the visco-elastic properties and cohesive dough formation (Kulp and Ponte, 2000).

On the other hand, a low-protein diet appears to enhance the conservative management of non-dialysis-dependent CKD
(Chronic Kidney Disease).And, may be considered as a potential option for CKD patients who wish to avoid or defer dialysis ignition, as well as slow down the progression of $\mathrm{CKD}$, while the risk of protein-energy wasting and cachexia remains minimal (Rhee et al., 2018).

Based on the finding of the meta-analysis, protein- restricted diet may reduce the rate of decline in renal function and the risk of kidney failure for CKD population, but did not produce a clear benefit for all causing death (Yan et al., 2018).

Novel functional snack foods, especially bakery products from the food industry (with potential health benefits) are in high demand by consumers. Numerous studies have assessed the production of bakery products (bread, biscuits, cookies and crackers) with health promoting ingredients, such as pulses, grains, and tubers (Julianti et al., 2017). 
Functional foods are growing on demand by health conscious consumers looking to improve their health and prevent diseases associated with aging. Crackers are a versatile thin and crispy food that can appeal to a variety of consumer expectations. They serve as a quick snack with low contents of moisture, sugar, and fat. The main ingredient in crackers is wheat flour, whose consumption may trigger celiac disease. Therefore, there is a need for food manufacturers to provide alternative gluten-free bakery products. While gluten free alternatives for bakery products such as bread, cakes, and biscuits are widely available, alternatives to crackers are not common (Ahmed and Abozed, 2015).

Cookies are important baked products that are considered the most desirable products for all ages due to their low manufacturing cost, long shelf life, convenience and good eating quality. Moreover, cookies could be used as a vehicle to deliver essential nutrients to $\mathrm{CD}$ patients who require an increase in their daily up take of nutrients due to intestinal damage (Beersand Berkow, 2004).

Rice could be a very useful ingredient, with a wide range of functional properties to enhance the quality of the finished product. Rice-based products are considered a feasible alternative (Sheng, 1995).

In the same line, Otegbayo et al.(2001) mentioned that parboiling as a means of rice processing affects both the physical and chemical properties, where it improves milling and cooking qualities of the rice grains in a positive manner, which was found to influence consumer demand and acceptability.

Potatoes are one of the most popular major food items consumed throughout the world because of their high yield, relatively low cost of production and adaptability to a wide variety of soil and climate types (Shirsatand Thomas, 1998).

Potatoes are a versatile food that are easy to prepare and can be eaten as a complementary vegetable or as a snack item (Chadha, 1994). Moreover, potatoes contribute significantly to the nutritive value of a meal as they contain good quality edible grade dietary fiber, several minerals and trace elements, essential vitamins and little or negligible fat (Misra and Kulshrestha, 2003).

These attributes make potato suitable for substituting for wheat flour in the preparation of bakery products. This also helps in lowering the gluten level and suitable for patients with coeliac disease. Addition of potato flour also enhances the sensory characteristics of biscuits (Tilman et al., 2003).

The objective of this study was to prepare cookies and crackers free of gluten and low in protein content by replacement of cornstarch with mashed potato or gelatinized rice flour or mixture of them and evaluating their chemical, physical and sensory properties.

\section{MATERIALS AND METHODS}

\subsection{Materials}

Potato, rice, cornstarch and other ingredients were purchased from the local market in Cairo, Egypt. Chemicals were of analytical reagent grade.

\subsection{Methods}

\subsubsection{Preparation of gelatinized rice flour}

The gelatinization of rice flour was prepared according to the method described by Taniguchi et al. (1988) as follows: rice grains were soaked for $3-4 \mathrm{~h}$ at $30^{\circ} \mathrm{C}$ followed by heating at $70^{\circ} \mathrm{C}$ for $40 \mathrm{~min}$ and steam cooked for $10 \mathrm{~min}$. After pre-gelatinization, rice grains were dried at $50^{\circ} \mathrm{C}$ in a circulating cabinet drier for 8 $\mathrm{h}$, then milled in Chopin CD1 mill and sieved through a 60 -mesh sieve $(250 \mu \mathrm{m})$. The resultant flour (pre-gelatinized rice flour) was stored in an airtight container at $4^{\circ} \mathrm{C}$.

\subsubsection{Preparation of cooked mashed potato}

Potato of approximately the same size were cooked in water for $30 \mathrm{~min}$. Cooked tubers were cooled, kept at $4^{\circ} \mathrm{C}$ for $12 \mathrm{~h}$, peeled and mashed with a Kenwood kitchen mixer (Peksa et al., 2002).

\subsubsection{Preparation of cookies and crackers}

Cookies and crackers prepared by partially replacing the cornstarch with gelatinized rice flour and mashed potato as shown in Table (1). Cookies dough was prepared according to Singh et al.(2008), while the method for crackers followed Sath et al.(1981).

\subsubsection{Proximate analysis of ingredients and products}

Gelatinized rice flour, cornstarch, mashed potatoes, cookies and crackers were analyzed for moisture, protein, ash, fat and crude fiber according to the methods of AOAC (2005). Total carbohydrate was calculated by difference. Mineral contents $(\mathrm{Ca}, \mathrm{Mg}, \mathrm{Fe}, \mathrm{Cu}$ and $\mathrm{Zn})$ were determined according to the method described by Chapman and Pratt (1978), whereas, phosphorus was determined by spectrophotometer according to Astm (1975). 
Table (1): Formula of cookies and crackers preparation.

\begin{tabular}{|c|c|c|c|c|c|c|c|c|c|c|}
\hline \multirow[b]{2}{*}{ Ingredients } & \multicolumn{5}{|c|}{ Cookies } & \multicolumn{5}{|c|}{ Crackers } \\
\hline & T0 & T1 & $\mathbf{T 2}$ & T3 & T4 & T5 & T6 & T7 & T8 & T9 \\
\hline Gelatinized Rice Flour & - & 30 & 20 & 10 & - & - & 30 & 20 & 10 & - \\
\hline Mashed Potato* & - & - & 10.52 & 21.05 & 31.57 & - & - & 10.52 & 21.05 & 31.57 \\
\hline Corn Starch & 100 & 70 & 70 & 70 & 70 & 100 & 70 & 70 & 70 & 70 \\
\hline Sugar & 30 & 30 & 30 & 30 & 30 & - & - & - & - & - \\
\hline Palm Oil & 30 & 30 & 30 & 30 & 30 & 10.00 & 10.00 & 10.00 & 10.00 & 10.00 \\
\hline Baking Powder & 2.5 & 2.5 & 2.5 & 2.5 & 2.5 & 2.5 & 2.5 & 2.5 & 2.5 & 2.5 \\
\hline Salt & 1 & 1 & 1 & 1 & 1 & 2 & 2 & 2 & 2 & 2 \\
\hline Water & \multicolumn{10}{|c|}{$\begin{array}{ll}1 & \text { As needed } \\
\end{array}$} \\
\hline $\begin{array}{l}\text { Note } * \text { Potato puree ratio } \\
\text { T0, T5 }=100 \% \text { corn starch } \\
\text { T1, T6 }=30 \% \text { gelatinized } \\
\text { T2, T7 }=20 \% \text { gelatinized } \\
\text { T3, T8 }=10 \% \text { gelatinized } \\
\text { T4, T9 }=31.57 \% \text { mashed }\end{array}$ & $\begin{array}{l}\text { calcul } \\
\text { f) (as } \\
\text { flour } \\
\text { flour } \\
\text { flour } \\
\text { to }(\mathrm{M}\end{array}$ & $\begin{array}{l}\text { on d } \\
\text { trol) } \\
\text { F) } \\
.52 \% \\
.05 \% \\
\text { as } 6 \%\end{array}$ & $\begin{array}{l}\text { shed po } \\
\text { ashed p }\end{array}$ & $\begin{array}{l}\text { o (as } 29 \\
\text { to (as } 4 \\
\text { t basis) }\end{array}$ & $\begin{array}{l}\text { n dry we } \\
\text { on dry w }\end{array}$ & $\begin{array}{l}\text { th basis) } \\
\text { ht basis) }\end{array}$ & ure) & & & \\
\hline
\end{tabular}

\subsubsection{Physical characteristics of cookies and crackers}

Cookies and crackers were evaluated for weight $(\mathrm{g})$, thickness $(\mathrm{mm})$, diameter $(\mathrm{mm})$ and spread ratio as described by Gaines (1991).Six cookies or crackers(edge-to-edge), were used for the evaluation of diameter and the average was noted. Diameter and thickness were measured using a Vernier Caliper. Spread ratio was calculated from the ratio of diameter to thickness and calculated using the following equation:

Spread ratio $=$ Diameter $/$ Thickness

2.2.6. Sensory evaluation of cookies and crackers

Cookie samples were organoleptically evaluated fortheir sensory characteristics according to the method of Larmond (1982). The samples were scored for color, flavor (odor and taste), texture and overall acceptability by ten trained panelists form Food Technology Research Institute.

Cracker samples were organoleptically evaluated for their sensory characteristics according to the method of Ihekoronye and Ngoddy (1985).Samples were scored for color, flavor (odor and taste), crispiness and overall acceptability by ten trained panelists form Food Technology Research Institute.

\subsubsection{Statistical analysis}

The analytical data were analyzed by using the procedure of the SPSS 16.0software system program (SPSS,2000). Means and standard deviations were determined using descriptive statistics. Comparisons between samples were determined using analysis of one-way variance (ANOVA) and multiple range tests. Statistical significance was defined at $\mathrm{P} \leq 0.05$.

\section{RESULT AND DISCUSSION}

\subsection{Chemical composition of ingredients.}

The results presented in Table (2) show the chemical composition of cornstarch, mashed potato and gelatinized rice flour (on dry weight basis). The results showed that protein, fat, carbohydrate, ash and crude fiber contents of corn starch were $(0.50,0.30,98.70,0.28$ and $0.22 \%$, respectively).Our results on starch agree with work by Swinkels (1985) who reported that the cereal starches (maize, wheat, waxy maize) contain a considerable amount of proteins $(0.25$ $0.5 \%)$

Gelatinized rice flour had high content of protein $(7.45 \%)$ when compared with corn starch $(0.50 \%)$ and mashed potato $(1.35 \%)$. Also, the results showed that it had $0.16 \%$ fat, $0.51 \%$ ash, $0.13 \%$ crude fiber and $91.75 \%$ carbohydrate.

These results on gelatinized rice flourare in agreement with the results of Mostafa (2014), who reported that the protein, ash and total carbohydrate contents of gelatinized rice flour (GRF) were $7.74 \%, \quad 0.71 \%$ and $88.05 \%$, respectively. 
Table (2): Chemical composition of ingredients.

\begin{tabular}{|l|c|c|c|}
\hline & Corn Starch & Mashed Potato & Gelatinized Rice Flour \\
\hline Moisture\% & $10.6 \pm 0.01$ & $81.00 \pm 0.15$ & $11.51 \pm 0.02$ \\
\hline Protein\% & $0.50 \pm 0.03$ & $1.35 \pm 0.01$ & $7.45 \pm 0.14$ \\
\hline Fat\% & $0.30 \pm 0.02$ & $0.13 \pm 0.05$ & $0.16 \pm 0.09$ \\
\hline Carbohydrate*\% & $98.70 \pm 0.15$ & $96.42 \pm 0.11$ & $91.75 \pm 1.12$ \\
\hline Ash\% & $0.28 \pm 0.04$ & $0.80 \pm 0.02$ & $0.51 \pm 0.03$ \\
\hline Fiber\% & $0.22 \pm 0.05$ & $1.30 \pm 0.04$ & $0.13 \pm 0.11$ \\
\hline Ca mg/100g & $2.00 \pm 0.03$ & $8.23 \pm 0.09$ & $4.25 \pm 0.09$ \\
\hline P $\mathbf{~ m g / 1 0 0 g ~}$ & $13.00 \pm 0.09$ & $19.89 \pm 0.05$ & $45.67 \pm 0.07$ \\
\hline Mg ml/100g & $3.00 \pm 0.11$ & $59.52 \pm 1.12$ & $5.68 \pm 0.05$ \\
\hline Fe $\mathbf{~ m g / 1 0 0 g}$ & $0.47 \pm 0.04$ & $0.75 \pm 0.01$ & $0.63 \pm 0.02$ \\
\hline Zn $\mathbf{~ m / 1 0 0 g}$ & $0.06 \pm 0.01$ & $0.25 \pm 0.03$ & $2.02 \pm 0.01$ \\
\hline
\end{tabular}

Values are means of three replicates \pm SD All analysis calculated on dry weight basis.

* Total carbohydrate was calculated by difference.

The decrease in protein due to the gelatinization processes may be a result of the leaching of protein during the process of soaking and cooking and rupturing that occurs in the molecules due to steaming. The process of parboiling makes the protein bodies to sink into the compact mass of gelatinized starch grains, making it less extractable and as a result a decrease in the protein content (Otegbayo et al.,2001). The same author explained the decrease in fat as a result of leaching and rupturing of the oil globules that occur due to the increase in temperature which occur through the gelatinization process. Carbohydrates of gelatinized rice was higher, may be as a result of starch gelatinization which makes the grain to expand, thus filling up the surrounding air space.

On the other hand, mashed potato had high contents of fiber and ash $(1.30 \%$ and $0.80 \%)$ when compared with cornstarch $(0.22 \%$ and $0.28 \%)$ and gelatinized rice flour $(0.13 \%$ and $0.51 \%$ ). Moreover, mashed potato had $0.13 \%$ of fat and $96.42 \%$ of carbohydrate.

Data on potato are in range of findings of Finglas and Faulks (1984) who reported mashed potatoes to contain $79-89 \%$ moisture, $1.8 \%$ protein, $0.1 \%$ fat and $1.4-2.0 \%$ fiber. Par-boiling of potatoes seemed to reduce the amount of crude fibre, ash, protein, and fat of mashed potatoes and sweet potatoes, which may be due to leaching as reported by Lyimo et al. (2010).

Higher value of ash content contributes to higher levels of mineral element in rice flour (Arendtand Zannini, 2013).As shown in Table (2), gelatinized rice flour had a higher mineral contents comparing with the mineral content of corn starch. Cornstarch had $2.0 \mathrm{mg} / 100 \mathrm{~g}$ of $\mathrm{Ca}$, $13.0 \mathrm{mg} / 100 \mathrm{~g}$ of $\mathrm{P}, 3.0 \mathrm{mg} / 100 \mathrm{~g}$ of $\mathrm{Mg}, 0.47$ $\mathrm{mg} / 100 \mathrm{~g}$ of $\mathrm{Fe}$ and $0.06 \mathrm{mg} / 100 \mathrm{~g}$ of zinc.
Minerals in cornstarch agree with work by Gwirtz and Garcia-Casa (2014).While, it was noticed that gelatinized rice had higher contents of $\mathrm{P}$ and $\mathrm{Zn}(45.67$ and $2.02 \mathrm{mg} / 100 \mathrm{~g}$ ). The results of calcium and zinc are in agreement with Kraithong and Rowdkuen(2019) who reported that $\mathrm{Ca}$ and $\mathrm{Zn}$ contents of rice were (5.36 and $2.46 \mathrm{mg} / 100 \mathrm{~g}$ ).

It could be noticed that, the highest increase was in mineral contents of mashed potato, especially, $\mathrm{Mg}$ and $\mathrm{Ca}$ contents (59.52 and 8.23 $\mathrm{mg} / 100 \mathrm{~g}$, respectively). It had $0.75 \mathrm{mg} / 100 \mathrm{~g}$ iron and $0.25 \mathrm{mg} / 100 \mathrm{~g}$ zinc. Minerals in mashed potatoes were in range of work reported by Rahman et al. (2015).

\subsection{Chemical composition of cookies and crackers}

The results presented in Table (3) show the chemical composition of low protein cookies (on dry weight basis). The protein, fat, ash, crude fiber and total carbohydrates contents of cookies produced from $100 \%$ cornstarch were $0.13 \%$, $14.93 \%, \quad 0.25 \%, \quad 0.35 \%$ and $84.34 \%$, respectively. These results are in range with work by Yaseen et al. (2014)who reported that ash and fiber were 0.25 and $0.24 \%$, respectively. While, the addition of gelatinized rice flour in cookies caused an increase in protein and ash (1.90 and $0.54 \%$, respectively). This may be explained by the higher protein and ash content in rice flour compared with starch.

The addition of $31.57 \%$ mashed potatoes, caused an increase in protein, fat, ash and fiber $(0.42,16.50,1.74$ and $0.68 \%$, respectively). The results showed that protein, fat, ash, crude fiber and total carbohydrates contents of crackers produced from $100 \%$ cornstarch were $0.15 \%$, $4.89 \%, 0.21 \%, 0.30 \%$ and $94.45 \%$, respectively. Adding 30\% gelatinized rice flour 
Table (3): Chemical composition of cookies and crackers

\begin{tabular}{|l|c|c|c|c|c|c|c|}
\hline Treatments & Moisture\% & Protein\% & Fat\% & $\begin{array}{c}\text { Carbohydrate* } \\
\%\end{array}$ & \multicolumn{2}{c|}{ Ash\% } & Fiber\% \\
\hline \multicolumn{7}{|c|}{ Cookies $^{*}$} \\
\hline T0 & $5.49 \pm 0.02^{\mathrm{e}}$ & $0.13 \pm 0.05^{\mathrm{e}}$ & $14.93 \pm 0.07^{\mathrm{e}}$ & $84.34 \pm 0.05^{\mathrm{a}}$ & $0.25 \pm 0.04^{\mathrm{e}}$ & $0.35 \pm 0.03^{\mathrm{e}}$ \\
\hline T1 & $5.99 \pm 0.05^{\mathrm{d}}$ & $1.90 \pm 0.03^{\mathrm{a}}$ & $14.95 \pm 0.01^{\mathrm{d}}$ & $82.14 \pm 0.07^{\mathrm{b}}$ & $0.54 \pm 0.02^{\mathrm{d}}$ & $0.47 \pm 0.08^{\mathrm{d}}$ \\
\hline T2 & $6.12 \pm 0.08^{\mathrm{c}}$ & $1.40 \pm 0.07^{\mathrm{b}}$ & $15.49 \pm 0.06^{\mathrm{c}}$ & $81.64 \pm 0.02^{\mathrm{c}}$ & $0.90 \pm 0.05^{\mathrm{c}}$ & $0.57 \pm 0.01^{\mathrm{c}}$ \\
\hline T3 & $6.27 \pm 0.03^{\mathrm{b}}$ & $0.95 \pm 0.08^{\mathrm{c}}$ & $16.08 \pm 0.03^{\mathrm{b}}$ & $81.35 \pm 0.02^{\mathrm{d}}$ & $1.01 \pm 0.01^{\mathrm{b}}$ & $0.61 \pm 0.05^{\mathrm{b}}$ \\
\hline T4 & $7.61 \pm 0.07^{\mathrm{a}}$ & $0.42 \pm 0.02^{\mathrm{d}}$ & $16.50 \pm 0.05^{\mathrm{a}}$ & $80.66 \pm 0.08^{\mathrm{e}}$ & $1.74 \pm 0.03^{\mathrm{a}}$ & $0.68 \pm 0.01^{\mathrm{a}}$ \\
\hline \multicolumn{7}{|c|}{ Crackers } \\
\hline T5 & $4.44 \pm 0.04^{\mathrm{e}}$ & $0.15 \pm 0.05^{\mathrm{e}}$ & $4.89 \pm 0.02^{\mathrm{e}}$ & $94.45 \pm 0.07^{\mathrm{a}}$ & $0.21 \pm 0.03^{\mathrm{e}}$ & $0.30 \pm 0.08^{\mathrm{e}}$ \\
\hline T6 & $4.86 \pm 0.08^{\mathrm{d}}$ & $1.83 \pm 0.02^{\mathrm{a}}$ & $4.95 \pm 0.07^{\mathrm{d}}$ & $92.35 \pm 0.05^{\mathrm{b}}$ & $0.45 \pm 0.03^{\mathrm{d}}$ & $0.42 \pm 0.04^{\mathrm{d}}$ \\
\hline T7 & $6.37 \pm 0.05^{\mathrm{c}}$ & $1.43 \pm 0.08^{\mathrm{b}}$ & $5.21 \pm 0.03^{\mathrm{c}}$ & $91.89 \pm 0.04^{\mathrm{c}}$ & $0.92 \pm 0.02^{\mathrm{c}}$ & $0.55 \pm 0.07^{\mathrm{c}}$ \\
\hline T8 & $8.04 \pm 0.02^{\mathrm{b}}$ & $1.00 \pm 0.03^{\mathrm{c}}$ & $5.51 \pm 0.04^{\mathrm{b}}$ & $91.54 \pm 0.18^{\mathrm{d}}$ & $1.35 \pm 0.08^{\mathrm{b}}$ & $0.60 \pm 0.05^{\mathrm{b}}$ \\
\hline T9 & $8.79 \pm 0.07^{\mathrm{a}}$ & $0.83 \pm 0.01^{\mathrm{d}}$ & $5.92 \pm 0.08^{\mathrm{a}}$ & $90.97 \pm 0.02^{\mathrm{e}}$ & $1.63 \pm 0.04^{\mathrm{a}}$ & $0.65 \pm 0.03^{\mathrm{a}}$ \\
\hline
\end{tabular}

Values are means of three replicates $\pm \mathrm{SD}$, numbers in the same column followed by the same letter are notSignificantly different at 0.05 level. All analysis calculated on dry weight basis.

* Total carbohydrate was calculated by difference.

$\mathrm{T} 0, \mathrm{~T} 5=100 \%$ corn starch $(\mathrm{CS})$ (as control)

$\mathrm{T} 1, \mathrm{~T} 6=30 \%$ gelatinized rice flour $(\mathrm{GRF})$.

$\mathrm{T} 2, \mathrm{~T} 7=20 \%$ gelatinized rice flour $+10.52 \%$ mashed potato (as $2 \%$ on dry weight basis).

$\mathrm{T} 3, \mathrm{~T} 8=10 \%$ gelatinized rice flour $+21.05 \%$ mashed potato (as $4 \%$ on dry weight basis)

$\mathrm{T} 4, \mathrm{~T} 9=31.57 \%$ mashed potato (MP)(as $6 \%$ on dry weight basis).

caused an increase in protein content from 0.15 $\%$ to $1.83 \%$ and in ash content from $0.21 \%$ to $0.45 \%$. Also, adding $31.57 \%$ of mashed potato caused an elevate in protein, fat, ash and fiber as $0.83,5.92,1.63$ and $0.65 \%$, respectively.

\subsection{Mineral content of cookies and crackers}

Dietary deficiency of micronutrients, specifically calcium and potassium, are highly associated with development of cardiovascular disorders (McCarron and Reusser, 2001). The results presented in Table (4) show the mineral content of low protein cookies (on dry weight basis). Results show that calcium, phosphorous, magnesium, iron, zinc and copper contents of cookies produced from $100 \%$ cornstarch were $18.137,9.085,0.507,0.106,0.009$ and 0.011 $\mathrm{mg} / 100 \mathrm{gm}$, respectively. While, the addition of $30 \%$ gelatinized rice flour caused an increase in all minerals (78.452, 36.129, 1.979, 0.409, 0.042 and $0.040 \mathrm{mg} / 100 \mathrm{gm}$, respectively). This may be explained by the higher mineral content in rice flour compared with starch. As for the addition of $31.75 \%$ mashed potatoes, it caused a higher increase in all minerals $(87.597,44.605,5.081$, $0.424,0.081$ and $0.064 \mathrm{mg} / 100 \mathrm{gm})$, respectively.

\subsection{Physical analysis of cookies and crackers}

Physical analysis of cookies and crackers are important from both consumers as well as manufacturers. Physical properties are shown in Table (5). Cookie dimensions were affected by the different proportions of cornstarch, gelatinized rice flour and mashed potato.

Results in Table (5) indicate that addition of different levels of mashed potatoes showed significant effects on the diameter of cookies and crackers. A decreasing trend was found with increasing the mashed potato levels.

Control treatments for cookies and crackers were exhibited a maximum diameter (38.64and 35.35 $\mathrm{mm}$, respectively), while cookies and crackers with $31.57 \%$ mashed potato exhibited a minimum diameter (36.44and $33.10 \mathrm{~mm}$, respectively). It is clear that enhancement in levels of potato significantly decreased the diameter of cookies and crackers which maybe attributed to an increase in fiber contents due to addition of potato, which is a rich source of dietary fiber. The results agree with those of Saini et al. (2017). 
Table (4): Mineral content of cookies and crackers

\begin{tabular}{|c|c|c|c|c|c|c|}
\hline Treatments & Camg/100g & Pmg/100g & Mgmg/100g & Femg/100g & Zn mg/100g & Cumg/100g \\
\hline \multicolumn{7}{|c|}{ Cookies } \\
\hline T0 & $18.137 \pm 0.04^{\mathrm{e}}$ & $9.085 \pm 0.08^{\mathrm{e}}$ & $0.507 \pm 0.02^{\mathrm{e}}$ & $0.106 \pm 0.03^{\mathrm{e}}$ & $0.009 \pm 0.05^{\mathrm{e}}$ & $0.011 \pm 0.07^{\mathrm{e}}$ \\
\hline T1 & $78.452 \pm 0.02^{\mathrm{d}}$ & $36.129 \pm 0.05^{\mathrm{d}}$ & $1.979 \pm 0.07^{\mathrm{d}}$ & $0.409 \pm 0.08^{b}$ & $0.042 \pm 0.01^{\mathrm{d}}$ & $0.040 \pm 0.03^{\mathrm{d}}$ \\
\hline $\mathbf{T} 2$ & $81.215 \pm 0.08^{c}$ & $37.723 \pm 0.03^{c}$ & $2.730 \pm 0.04^{\mathrm{c}}$ & $0.364 \pm 0.02^{\mathrm{d}}$ & $0.049 \pm 0.07^{\mathrm{c}}$ & $0.043 \pm 0.05^{\mathrm{c}}$ \\
\hline T3 & $84.942 \pm 0.05^{b}$ & $41.197 \pm 0.07^{b}$ & $3.850 \pm 0.08^{b}$ & $0.396 \pm 0.01^{\mathrm{c}}$ & $0.065 \pm 0.03^{b}$ & $0.053 \pm 0.02^{b}$ \\
\hline $\mathbf{T 4}$ & $87.597 \pm 0.03^{\mathrm{a}}$ & $44.605 \pm 0.02^{\mathrm{a}}$ & $5.081 \pm 0.01^{\mathrm{a}}$ & $0.424 \pm 0.05^{\mathrm{a}}$ & $0.081 \pm 0.08^{\mathrm{a}}$ & $0.064 \pm 0.04^{\mathrm{a}}$ \\
\hline \multicolumn{7}{|c|}{ Crackers } \\
\hline T5 & $0.831 \pm 0.01^{\mathrm{e}}$ & $3.866 \pm 0.06^{\mathrm{e}}$ & $0.065 \pm 0.05^{\mathrm{e}}$ & $0.127 \pm 0.04^{\mathrm{e}}$ & $0.003 \pm 0.06^{\mathrm{e}}$ & $0.015 \pm 0.01^{\mathrm{e}}$ \\
\hline T6 & $2.403 \pm 0.05^{\mathrm{d}}$ & $12.597 \pm 0.07^{\mathrm{d}}$ & $2.926 \pm 0.08^{\mathrm{d}}$ & $0.377 \pm 0.06^{\mathrm{d}}$ & $0.060 \pm 0.01^{\mathrm{d}}$ & $0.049 \pm 0.06^{\mathrm{d}}$ \\
\hline T7 & $2.445 \pm 0.06^{\mathrm{c}}$ & $13.872 \pm 0.01^{\mathrm{c}}$ & $4.438 \pm 0.04^{c}$ & $0.433 \pm 0.07^{\mathrm{c}}$ & $0.076 \pm 0.08^{c}$ & $0.056 \pm 0.05^{c}$ \\
\hline T8 & $3.131 \pm 0.04^{b}$ & $19.460 \pm 0.08^{b}$ & $7.086 \pm 0.03^{b}$ & $0.462 \pm 0.04^{b}$ & $0.113 \pm 0.01^{\mathrm{b}}$ & $0.080 \pm 0.07^{b}$ \\
\hline T9 & $3.950 \pm 0.07^{\mathrm{a}}$ & $26.059 \pm 0.01^{\mathrm{a}}$ & $10.188 \pm 0.07^{\mathrm{a}}$ & $0.501 \pm 0.01^{\mathrm{a}}$ & $0.157 \pm 0.04^{\mathrm{a}}$ & $0.107 \pm 0.01^{a}$ \\
\hline
\end{tabular}

Values are means of three replicates \pm SD, numbers in the same column followed by the same letter are notsignificantly different at 0.05 level. All analysis calculated on dry weight basis.

T0, T5 $=100 \%$ corn starch (CS) (as control)

$\mathrm{T} 1, \mathrm{~T} 6=30 \%$ gelatinized rice flour $(\mathrm{GRF})$

$\mathrm{T} 2, \mathrm{~T} 7=20 \%$ gelatinized rice flour $+10.52 \%$ mashed potato (as $2 \%$ on dry weight basis)

$\mathrm{T} 3, \mathrm{~T} 8=10 \%$ gelatinized rice flour $+21.05 \%$ mashed potato (as $4 \%$ on dry weight basis)

$\mathrm{T} 4, \mathrm{~T} 9=31.57 \%$ mashed potato (MP) (as $6 \%$ on dry weight basis

Table (5): Physical properties of cookies and crackers.

\begin{tabular}{|l|c|c|c|c|}
\hline Treatments & $\begin{array}{c}\text { Diameter } \\
(\mathbf{m m})\end{array}$ & $\begin{array}{c}\text { Thickness } \\
(\mathbf{m m})\end{array}$ & Spread Ratio (D/T) & $\begin{array}{c}\text { Weight } \\
(\mathbf{g})\end{array}$ \\
\hline \multicolumn{5}{|c|}{ Cookies } \\
\hline T0 & $38.64 \pm 0.15^{\mathrm{a}}$ & $5.25 \pm 0.19^{\mathrm{a}}$ & $7.36 \pm 0.14^{\mathrm{a}}$ & $6.34 \pm 0.17^{\mathrm{b}}$ \\
\hline T1 & $37.97 \pm 0.12^{\mathrm{b}}$ & $5.20 \pm 0.15^{\mathrm{b}}$ & $7.30 \pm 0.19^{\mathrm{b}}$ & $6.64 \pm 0.14^{\mathrm{a}}$ \\
\hline T2 & $37.45 \pm 0.11^{\mathrm{c}}$ & $5.18 \pm 0.14^{\mathrm{c}}$ & $7.23 \pm 0.17^{\mathrm{c}}$ & $6.15 \pm 0.12^{\mathrm{c}}$ \\
\hline T3 & $37.00 \pm 0.19^{\mathrm{d}}$ & $5.13 \pm 0.12^{\mathrm{d}}$ & $7.21 \pm 0.15^{\mathrm{d}}$ & $5.35 \pm 0.10^{\mathrm{d}}$ \\
\hline T4 & $36.44 \pm 0.14^{\mathrm{e}}$ & $5.09 \pm 0.17^{\mathrm{e}}$ & $7.16 \pm 0.12^{\mathrm{e}}$ & $5.08 \pm 0.19^{\mathrm{e}}$ \\
\hline \multicolumn{5}{|c|}{} \\
\hline T5 & Crackers & $9.63 \pm 0.13^{\mathrm{a}}$ & $3.54 \pm 0.14^{\mathrm{b}}$ \\
\hline T6 & $35.35 \pm 0.17^{\mathrm{a}}$ & $3.67 \pm 0.15^{\mathrm{a}}$ & $9.59 \pm 0.11^{\mathrm{b}}$ & $3.60 \pm 0.10^{\mathrm{a}}$ \\
\hline T7 & $34.71 \pm 0.15^{\mathrm{b}}$ & $3.62 \pm 0.14^{\mathrm{b}}$ & $9.58 \pm 0.19^{\mathrm{c}}$ & $3.54 \pm 0.15^{\mathrm{b}}$ \\
\hline T8 & $34.30 \pm 0.13^{\mathrm{c}}$ & $3.58 \pm 0.17^{\mathrm{c}}$ & $9.55 \pm 0.17^{\mathrm{d}}$ & $3.48 \pm 0.19^{\mathrm{c}}$ \\
\hline T9 & $33.71 \pm 0.19^{\mathrm{d}}$ & $3.53 \pm 0.14^{\mathrm{d}}$ & $9.51 \pm 0.15^{\mathrm{e}}$ & $3.21 \pm 0.13^{\mathrm{d}}$ \\
\hline
\end{tabular}

Values are means of three replicates \pm SD, numbers in the same column followed by the same letter are notSignificantly different at 0.05 level.

$\mathrm{T} 0, \mathrm{~T} 5=100 \%$ corn starch (CS) (as control).

$\mathrm{T} 1, \mathrm{~T} 6=30 \%$ gelatinized rice flour $(\mathrm{GRF})$

$\mathrm{T} 2, \mathrm{~T} 7=20 \%$ gelatinized rice flour $+10.52 \%$ mashed potato (as $2 \%$ on dry weight basis)

$\mathrm{T} 3, \mathrm{~T} 8=10 \%$ gelatinized rice flour $+21.05 \%$ mashed potato (as $4 \%$ on dry weight basis)

$\mathrm{T} 4, \mathrm{~T} 9=31.57 \%$ mashed potato (MP) (as $6 \%$ on dry weight basis 
The thickness of cookies and crackers decreased significantly from $5.25 \mathrm{~mm}$ to $5.09 \mathrm{~mm}$ for cookies, and from 3.67 to $3.48 \mathrm{~mm}$ for crackers. It is evident that increased levels of potato significantly decreased the thickness of cookies and crackers. These results are in accordance with those of Saeed et al. (2012)and Omran and Hussien (2015) who observed that thickness of cookies decreased with increasing sweet potato flour percentage.

The results of spread ratio of cookies and crackers revealed a reduction from 7.36 (control) to 7.16 , for cookies, and from 9.63 to 9.51 , for crackers among treatments as the level of potato was increased. These results are in line with the findings of Vieira et al. (2007) who established that spread is strongly correlated to the water absorption capacities of the flour. Singh et al. (2008) explained this by the strong waterbinding characteristics of sweet potato which rendered cookie dough "drier" in appearance than the dough containing rice flour only. Consequently, the dough could not spread well, and the cookies were small and dense.

Doescher et al. (1987) explained the negative relationship between the highly hydrophilic starches and cookie spread for both flours illustrates the competitive nature of hydrophilic flour components for mobile formula water and the resulting influence over cookie spread. The gross hydrophilic components of a sugar-snap cookie formula are flour and sugar. If flour components are less hydrophilic, more water is available to the sugar to form syrup and decrease the dough viscosity during baking, resulting in greater dough spreading and larger cookie diameter. Elevating the hydrophilic characteristics of flour components directly decreases cookie spread.

\subsection{Sensory characteristics of cookies and crackers.}

Kuenzel et al.(2011)reported that sensory evaluation is a unique discipline that makesuse of experimental design and statistical analysis concepts to human senses, with the aim of evaluating consumer products.

Cookies produced from different levels of mashed potato and gelatinized rice were sensory-evaluated and compared with control (100\% cornstarch)and results are shown in Table (6).

Table (6): Sensory characteristics of cookies and crackers.

\begin{tabular}{|c|c|c|c|c|c|}
\hline Treatment & $\begin{array}{l}\text { Color } \\
(9)\end{array}$ & $\begin{array}{c}\text { Taste } \\
\text { (9) }\end{array}$ & $\begin{array}{l}\text { Odor } \\
(9)\end{array}$ & $\begin{array}{l}\text { Texture } \\
\text { (9) }\end{array}$ & $\begin{array}{c}\text { Overall } \\
\text { acceptability }(9)\end{array}$ \\
\hline \multicolumn{6}{|c|}{ Cookies } \\
\hline T0 & $5.30 \pm 0.15^{\mathrm{e}}$ & $3.21 \pm 0.19^{\mathrm{e}}$ & $5.36 \pm 0.14^{\mathrm{e}}$ & $6.34 \pm 0.17^{\mathrm{e}}$ & $5.55 \pm 0.12^{\mathrm{e}}$ \\
\hline T1 & $7.33 \pm 0.12^{\mathrm{d}}$ & $4.25 \pm 0.15^{\mathrm{d}}$ & $6.31 \pm 0.19^{d}$ & $6.39 \pm 0.14^{\mathrm{d}}$ & $6.66 \pm 0.17^{\mathrm{d}}$ \\
\hline T2 & $7.97 \pm 0.11^{\mathrm{c}}$ & $5.19 \pm 0.14^{b}$ & $7.25 \pm 0.17^{b}$ & $6.61 \pm 0.12^{\mathrm{c}}$ & $7.24 \pm 0.19^{b}$ \\
\hline T3 & $8.32 \pm 0.19^{b}$ & $5.15 \pm 0.12^{\mathrm{c}}$ & $7.20 \pm 0.15^{\mathrm{c}}$ & $6.75 \pm 0.10^{\mathrm{b}}$ & $7.87 \pm 0.11^{\mathrm{a}}$ \\
\hline T4 & $8.51 \pm 0.14^{\mathrm{a}}$ & $5.20 \pm 0.17^{\mathrm{a}}$ & $7.51 \pm 0.12^{\mathrm{a}}$ & $7.38 \pm 0.19^{\mathrm{a}}$ & $6.87 \pm 0.15^{\mathrm{c}}$ \\
\hline \multicolumn{6}{|c|}{ Crackers } \\
\hline Treatments & $\begin{array}{l}\text { Color } \\
(9)\end{array}$ & $\begin{array}{c}\text { Taste } \\
(9)\end{array}$ & $\begin{array}{l}\text { Odor } \\
(9)\end{array}$ & $\begin{array}{c}\text { Crispiness } \\
\text { (9) }\end{array}$ & $\begin{array}{c}\text { Overall } \\
\text { acceptability } \\
(9)\end{array}$ \\
\hline T5 & $6.10 \pm 0.11^{\mathrm{e}}$ & $3.85 \pm 0.19^{\mathrm{e}}$ & $5.08 \pm 0.15^{\mathrm{e}}$ & $5.21 \pm 0.13^{\mathrm{e}}$ & $5.75 \pm 0.1 \mathrm{e}^{\mathrm{e}}$ \\
\hline T6 & $6.35 \pm 0.15^{\mathrm{d}}$ & $4.60 \pm 0.14^{\mathrm{d}}$ & $6.32 \pm 0.11^{\mathrm{d}}$ & $6.06 \pm 0.14^{\mathrm{d}}$ & $6.86 \pm 0.17^{\mathrm{c}}$ \\
\hline T7 & $7.01 \pm 0.13^{\mathrm{c}}$ & $5.30 \pm 0.17^{\mathrm{c}}$ & $7.35 \pm 0.19^{c}$ & $6.97 \pm 0.15^{b}$ & $7.34 \pm 0.19^{b}$ \\
\hline T8 & $7.35 \pm 0.19^{b}$ & $6.02 \pm 0.14^{b}$ & $7.62 \pm 0.17^{\mathrm{a}}$ & $7.04 \pm 0.19^{\mathrm{a}}$ & $7.89 \pm 0.11^{\mathrm{a}}$ \\
\hline T9 & $7.89 \pm 0.17^{\mathrm{a}}$ & $6.67 \pm 0.15^{\mathrm{a}}$ & $7.41 \pm 0.13^{b}$ & $6.54 \pm 0.14^{\mathrm{c}}$ & $6.80 \pm 0.15^{\mathrm{d}}$ \\
\hline
\end{tabular}

Values are means of three replicates \pm SD, numbers in the same column followed by the same letter are notSignificantly different at 0.05 level.

$\mathrm{T} 0, \mathrm{~T} 5=100 \%$ corn starch $(\mathrm{CS})$ (as control).

$\mathrm{T} 1, \mathrm{~T} 6=30 \%$ gelatinized rice flour $(\mathrm{GRF})$

$\mathrm{T} 2, \mathrm{~T} 7=20 \%$ gelatinized rice flour $+10.52 \%$ mashed potato (as $2 \%$ on dry weight basis)

$\mathrm{T} 3, \mathrm{~T} 8=10 \%$ gelatinized rice flour $+21.05 \%$ mashed potato (as $4 \%$ on dry weight basis)

$\mathrm{T} 4, \mathrm{~T} 9=31.57 \%$ mashed potato (MP) (as $6 \%$ on dry weight basis 
The texture of mashed potato and gelatinized rice flour cookies and crackers were more acceptable than those made from cornstarch only.

The score of flavor (taste and odor) increased significantly as the addition of mashed potato was increased in cookies and crackers. In addition, the color, texture, taste and overall acceptability increased significantly.

These results agree with those reported by Kaur and Aggarwal (2015) on the development of potato rice papads, which reported that the color of potato products is the most significant visual quality criterion, which is dependent on the amount of reducing sugars in raw tubers because they induce a non-enzymatic Millard reaction with free amino acids.

As can be seen, the sensory score shows that the formula with $10 \%$ gelatinized rice flour $+21.05 \%$ mashed potato (as $4 \%$ on dry weight basis) $+70 \%$ corn starch is the most acceptable formula for both cookies and crackers, with reference to overall acceptability.

\section{Conclusion}

The present study produced crackers and cookies with various ratios of gelatinized rice flour and mashed potato mixtures with cornstarch. It was found that the addition of gelatinized rice flour and mashed potato caused an increase in protein, ash and minerals. A decreasing trend was found with increasing the mashed potato levels on diameter and the spread ratio of cookies and crackers, whereas, it is evident that increased levels of potato significantly decreased the thickness of cookies.

Also, it can be concluded that the sensory score shows that the formula with $10 \%$ gelatinized rice flour $+21.05 \%$ mashed potato (as $4 \%$ on dry weight basis) $+70 \%$ corn starch is the most acceptable formula for both cookies and crackers, with reference to overall acceptability.

\section{REFERENCES}

Ahmed Z.S. and Abozed S.S. (2015). Functional and antioxidant properties of novel snack crackers incorporated with Hibiscus sabdariffa by-product. J. Adv. Res. 6 (1):79-87.

AOAC (2005). Official Methods of Analysis of the Association of Official Analytical Chemists.18th Edition, Washington DC., USA.
Arendt E.K. and Zannini E. (2013). Rice: cereal grains for the food and beverage industries. Woodhead Publishing: Cambridge Share. Pp. 512.

Astm S. (1975).In: Annual book of American society of testing materials standard water. Part 31 Dsis-72-Philadelphia, PA., USA.

Beers M. and Berkow R. (2004).The Merck Manual of Diagnosis and Therapy. Merck Res. Lab., USA.

Chadha K.L.(1994). Potato: a future food crop of India. J. Indian Potato Assoc., 21(1-2): 7 20.

Chapman H.D. and Pratt P.F. (1978). Method of analysis for soils, plants and water. Univ. of California, Div. Agric. Sci., Ca. USA, pp: 50.

Doescher L.C., Milliken R.C. and Rubenthaler G.L. (1987). Effect of sugar and flours on cookies spread evaluated by time-lapse photography. Cereals Chem., 64: 163167.

Finglas P. M. and Faulks R. M. (1984).Nutritional composition of UK retail potatoes, both raw and cooked. J. Sci. Food Agric., 35(12):1347-1356.

Gaines C.S. (1991). Instrumental measurement of the hardness of cookies and crackers. Cereal Foods World, 36: 989-996.

Gwirtz J.A. and Garcia-CasalM.N. (2014). Processing maize flour and corn meal food products. Annals of the New York Academy of Sciences, 1312(1), p.66.

Hussain S., Anjum F.M., Butt M.S., Khan M.I. and Asghar A. (2006). Physical and sensory attributes of flaxseed flour supplemented cookies. Turk J. Biol., 30: 87-92.

Ihekoronye A.I. and Ngoddy P.O. (1985). Integrated food science and technology for the tropics. Macmillan Education Ltd. Pp.189.

Julianti E., Rusmarilin H., Ridwansyah. and Yusraini E.(2017). Functional and rehological properties of composite flourfrom sweet potato, maize, soybean and xanthan gum. J. Saudi Soc. Agric. Sci., 16(2):171-177.

Kaur S. and Aggarwal P. (2015). Development and evaluation of nutritionally enhanced potato rice papads (Indian cookie). J. Appl. Nat. Sci., 7(1): 242-248.

Kaur A., Kochhar A., and Prasad P. (2015). Development and nutritional evaluation of products using potato flour for 
malnourished children. Int'1 J. Health Sci. Res., 5(6):554-560.

Kraithong S. and Rawdkuen S. (2019). The effect of chemical composition ofrice flour on physico-chemical and functional properties.Prawarun Agric. J., 16(1): 4970.

Kuenzel J., Zandstra E.H., El Deredy W., Blanchette I. and Thomas A. (2011) Expecting yoghurt drinks to taste sweet or pleasant increases liking. Appetite, 56(1): 122-127.

Kulp K. and Ponte J. (2000). In: Hand Book of Cereal Science and Technology. Marcel Dekker Inc., New York, USA.

Larmond E. (1982) Laboratory methods of sensory evaluation of food. Research branch. Canada Department of AgriculturePublications.

Lerner A. (2010).New therapeutic strategies for celiac disease. Autoimmun. Rev. 9: 144147.

LyimoM.E., Gimbi D.M. and Kihinga T. (2010).Effect of processing methods on nutrient contents of six sweet potato varieties grown in lake zone of Tanzania. TanzaniaJ. Agric. Sci., 10(1): 55-61.

McCarron D.A. and Reusser M.E. (2001). Are low intakes of calcium and potassium important causes of cardiovascular disease? Amer.J.Hypertension, 14(S3):206 S-212S.

Misra A. and KulshresthaK.(2003). Potato flour incorporation in biscuit manufacture, Plant Foods Hum.Nutr., 58(2): 1-9.

Mostafa S. M. T. M. (2014). Production and evaluation of some functional foods for celiac patients. M.Sc. Thesis, Food Sci. Dept., Fac. of Agric., Cairo Univ.

Omran A. A. and Hussien H. A. (2015). Production and evaluation of gluten-free cookies from broken rice and sweet potato. Adv. Food Sci., 36(4): 184-191.

Otegbayo B. O., Osamuel F. and Fashakin J. B. (2001). Effect of parboiling on physicochemical qualities of two local rice varieties in Nigeria. J. Food Tech.Afr., 6(4): 130-132.

Peksa A.B., Apeland J., Gronnerod S. and Magnus E.M. (2002).Comparison of the consistencies of cooked mashed potato prepared from seven varieties of potatoes.Food Chem., 76: 311-317.

Rahman M.A., Ali M.A., Hasan S.K. and Sarker M., (2015). Effects of peeling methods on mineral content of potato and development of potato based biscuit. International Journal of Nutrition and Food Science, 4(6): 669-675.

Rhee C.M., Ahmadi S.F., Kovesdy C.P. and Kalantar-Zadeh K. (2018). Low-protein diet for conservative management of chronic kidney disease: a systematic review and meta-analysis of controlled trials. J. Cachexia Sarcopenia Muscle,Apr.,9(2): 235-245.

Saeed S., Ahmad M.M., Kausar H, Parveen S, Masih S. and Salam A. (2012) Effect of sweet potato flour on quality of cookies. J. Agric. Res., 50(4): 525-538.

Saini P., Yadav N., Kaur D.K., Gupta V., Kaundal B., Mishra P., Mishra A. and Kumar R. (2017). Physicochemical, functional and biscuit making properties of wheat flour and potato flour blends. Curr.Nutr.\& Food Sci., 13(3): 192-197.

Sath S. K., Tamhane D. and Salunkhe D. K. (1981). Studies in saltine crackers (khara biscuits); II. Protein enrichment and storage stability. Cereal Food World, 26(8): 407-409.

Sheng D. (1995). Rice based ingredients in cereal and snacks. Cereal Chem., 40: 538540.

Shirsat S.G. and ThomasP.(1998). Effect of irradiation and cooking methods on ascorbic acid levels of four potato cultivars. J. Food Sci. Tech., 35(6):509514.

Singh S., Riar C.S. and Saxena D.C. (2008). Effect of incorporating sweetpotato flour to wheat flour on the quality characteristics of cookies. Afr. J. Food Sci., 2: 065-072.

SPSS (2000). Statistical package for Social Sciences. SPSS forWindows, Version 10, SPSS Inc., Chicago, IL, USA.

SwinkelsJ.J.M. (1985). Composition and properties of commercial native starches. Starch-Stärke, 37(1): 1-5.

Taniguchi M., Nakanaga R. and Yano N. (1988). Method of manufacturing dried rice with pre-gelatinizedstarch content. United States Patent, An 89-06-V0106.

Tilman J.C., Colm M.O.B., DeniseM.C., Anja D. and ElkeKA. (2003). Influence of gluten free flour mixes and fat powder on the quality of gluten free biscuits. Eur. Food Res. Tech., 216: 369-376. 
VieiraM.A.,Tramonte K.C.,Podestá R.,Avancini S.R.P.,Amboni R.D.M.C. and Amante E.R. (2007). Physicochemical and sensory characteristics of cookies containing residue from king palm (Archontophoenixalexandrae) processing. Int. J. Food Sci. Tech., 43, 1534-1540.

Yan B., Su X., Xu B., Qiao X. and Wang L.
(2018). Effect of diet protein restriction on progression of chronic kidney disease: A systematic review and meta-analysis. Plos.one, 13(11): 1-19.

Yaseen A.A.,Shouk A.A. and Bareh G. (2014). Production of functional biscuits for phenylketonuria patients. World Appl. Sci. J., 31(5): 692-697.

\author{
تحضير كوكيز ومقرمشات خالية الجلوتين قليلة المحتوى من البروتين \\ جيرمين صالح فهيم ـ نادية محمود عبد المطلب ـ حنان عبد الحميد حسين \\ قسم بحوث الخبز والعجائن - معهج بحوث تكنولوجيا الاغذية ـ مركز البحوث الزراعية ـ الجبزة ـ مصر
}

يهدف البحث لاستخدام خلطات من دقيق الأرز المجلتن وبيوريه البطاطس المسلوقة مع نشا الذرة لتحضير الكوكيز

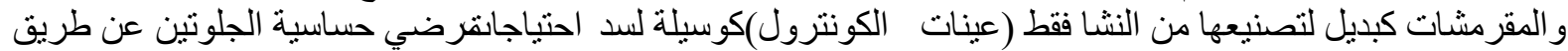

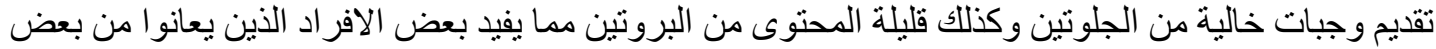

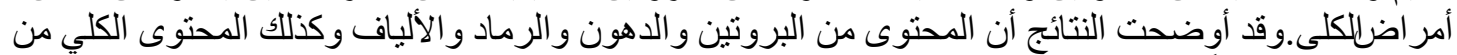

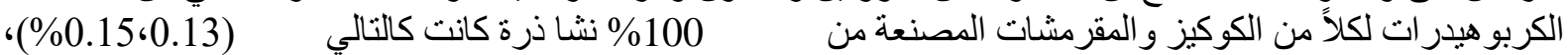

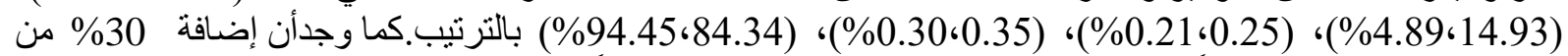

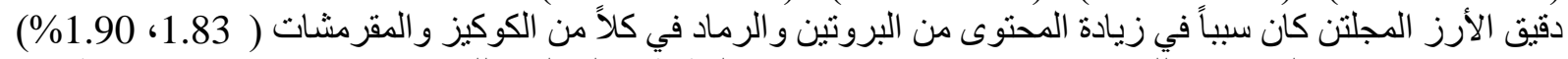

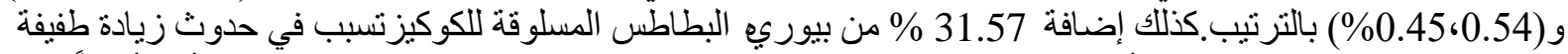
في البروتين و الدهون و الرماد و الألياف كالتالي (

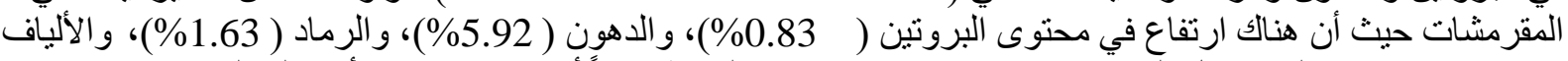

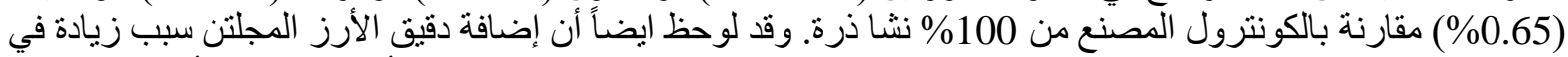

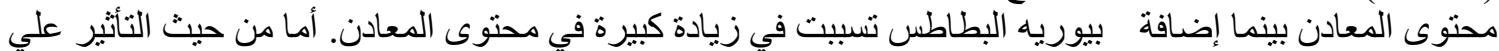

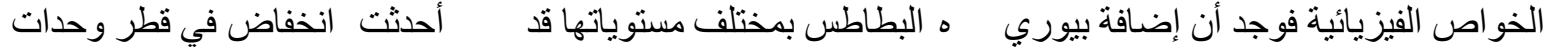

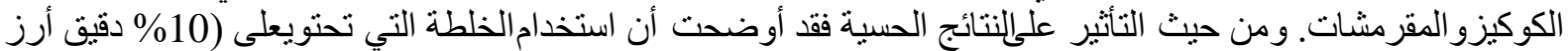

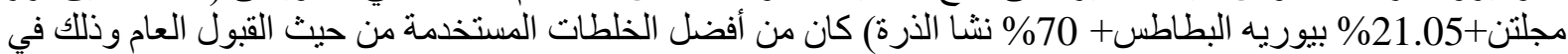
كلاً من الكوكيز و المقرمشات.

المجلة العلمية لكلية الزراعة - جامعة القاهرة- المجلد (72) العددالاول يناير (2021): 13-22. 